\title{
Changes in herbage mass and time of herbage allocation modify nutritional and metabolic status of dairy cows
}

\author{
Ālvaro Morales ${ }^{1}$, Marisol Godoy ${ }^{1}$, Ignacio Beltrān ${ }^{1}$, Ananda Muller ${ }^{1}$, Oscar Balocchi², and Rubén Pulido ${ }^{1 *}$ \\ ${ }^{1}$ Universidad Austral de Chile, Facultad de Ciencias Veterinarias, PO Box 567, Valdivia, Chile. \\ *Corresponding author (rpulido@uach.cl). \\ ${ }^{2}$ Universidad Austral de Chile, Facultad de Ciencias Agronómicas, PO Box 567, Valdivia, Chile.
}

Received: 20 March 2018; Accepted: 25 July 2018; doi:10.4067/S0718-58392018000300409

\begin{abstract}
In temperate milk production systems, it is important to study the effect of grazing strategies in both the quantity and quality of the diet, resulting in potential impacts on animal metabolism. The aim was to evaluate the effect of timing of herbage allocation and herbage mass on blood indicators. Forty Holstein-Friesian cows were grouped according to milk production $\left(24.7 \pm 2.8 \mathrm{~kg} \mathrm{cow}^{-1}\right)$, body weight $(580.6 \pm 51.7 \mathrm{~kg})$ and days in milk $(74 \pm 17.1 \mathrm{~d})$. The groups were randomly allocated to one of four treatments: 1) L-AM, access to new herbage allocation after morning milking with herbage mass of $2000 \mathrm{~kg} \mathrm{DM} \mathrm{ha}^{-1}$; 2) L-PM; access to new herbage allocation after afternoon milking with herbage mass of $2000 \mathrm{~kg}$ $\mathrm{DM} \mathrm{ha}^{-1}$; 3) $\mathrm{H}-\mathrm{AM}$; access to new herbage allocation after morning milking with herbage mass of $3000 \mathrm{~kg} \mathrm{DM} \mathrm{ha}^{-1}$; 4 ) $\mathrm{H}-\mathrm{PM}$; access to new herbage allocation after afternoon milking with herbage mass of $3000 \mathrm{~kg} \mathrm{DM} \mathrm{ha}^{-1}$. Milk production was only different for H-PM in $1.1 \mathrm{~kg}$ higher than L-PM. Urea in milk was affected by treatments, being $22 \%$ higher for L-AM than other treatments. $\beta$-Hydroxybutyrate and blood urea concentrations were $47 \%$ and $30 \%$ higher, respectively, for AM compared to PM treatments. Plasma albumin concentration was lower for H-PM compared to other treatments at week 3 of blood sampling. PM treatments modify the herbage composition and animal metabolism, while combining it with a high herbage mass impacts positively in production and milk composition.
\end{abstract}

Key words: Autumn pasture, dairy cows, grazing system, metabolism, pasture management.

\section{INTRODUCTION}

Understanding the needs of the pasture plant and the interaction between the animal and the plant is essential in grazing dairy production systems. Thus, grazing management has focused on controlling the factors that influence the pasture growth, quality, and utilization, modifying through the frequency and intensity of grazing the pasture consumed by the cows, and thereby, the milk production (Badgery et al., 2017; Roche et al., 2017). On the other hand, there is a lot of information of livestock management tools in grazing systems (e.g., body condition score, measuring and weighing of growth, monitoring of behavior, among others), which are associated with a near maximum milk production and expression of the genetic merit of the cow, while it would ensure that reproduction, health and animal welfare are not compromised (Roche et al., 2009). However, these tools are not a sufficiently sensitive measure and only can be associated with general health status (Roche et al., 2013), being necessary to accompany these tools with monitoring through blood profiles. In addition, it is necessary to generate more information on how monitor the health of cows and also how it interacts with the grazing management, especially in early lactation (Morales et al., 2016). 
Additionally, in conditions of herbage shortage, i.e., dry summers, autumn and winter, it is difficult to ensure a stable supply of nutrients to cows, due to variations in the DM content, imbalances in the nutritional composition of pasture (Pulido et al., 2015; Ruiz Albarrán et al., 2016a), and mainly due to low DM intake and energy intake (Morales et al., 2014). Metabolic disorders of nutritional origin occur at defined periods of the year and are due to deficiencies or excesses of energy, proteins and/or minerals. Most of these imbalances are of difficult perception, however, they act by decreasing persistently the production and profitability of dairy farm (Sundrum, 2015). Thus, in the last time some studies have been focused on use of grazing strategies -change in the amount of herbage mass offered to the cows and the timing of pasture allocation-, to modify the diet (quantity and/or quality) and the consumption pattern of pasture, monitoring its impact on the productive level of cows (Wims et al., 2010; Pulido et al., 2015; Vibart et al., 2017). However, there is little information on the effect of these grazing strategies on indicators of protein and energy metabolism (Pulido et al., 2015), and there is even no evidence of the interaction between both factors, ignoring the potential of these tools to optimize the use of the pasture when it is limited (Vibart et al., 2017).

The aim of this study was to evaluate the effect of timing of herbage allocation and herbage mass on blood indicators of energy and protein metabolism of early lactation dairy cows during autumn.

\section{MATERIALS AND METHODS}

\section{Experimental site, animals, and treatments}

Animal handling and treatments described in this experiment were approved by the Animal Welfare Committee of the Universidad Austral de Chile. The experiment was carried out between 5 May and 1 July 2016 at the Agriculture Austral Research Station of the Universidad Austral de Chile, Valdivia (39 $47^{\prime} \mathrm{S}$ and $73^{\circ} 14^{\prime} \mathrm{W}$, annual rainfall $2500 \mathrm{~mm}$ ). The first $14 \mathrm{~d}$ of the experiment were considered as adaptation period and a 43- $\mathrm{d}$ measurement period.

Forty Holstein-Friesian cows were grouped according to milk production $\left(24.7 \pm 2.8 \mathrm{~kg} \mathrm{cow}^{-1}\right)$, body weight (BW; $580.6 \pm 51.7 \mathrm{~kg}$ ), days in milk (DIM; $74 \pm 17.1)$ and body condition score (BCS; $3.1 \pm 0.3)$. The groups $(\mathrm{n}=10)$ were randomly allocated to one of four treatments: 1) L-AM, access to new herbage allocation after morning milking with herbage mass of $2000 \mathrm{~kg} \mathrm{DM} \mathrm{ha}^{-1}$;2) L-PM, access to new herbage allocation after afternoon milking with herbage mass of $2000 \mathrm{~kg} \mathrm{DM} \mathrm{ha}^{-1}$; 3) H-AM, access to new herbage allocation after morning milking with herbage mass of $3000 \mathrm{~kg}$ $\mathrm{DM} \mathrm{ha}^{-1}$; 4) H-PM, access to new herbage allocation after afternoon milking with herbage mass of $3000 \mathrm{~kg} \mathrm{DM} \mathrm{ha}^{-1}$. All cows were supplemented with $3.5 \mathrm{~kg} \mathrm{DM} \mathrm{d}^{-1}$ of concentrate, which was divided into equal amounts during both milking times $(07: 00 \mathrm{~h}$ and $14: 00 \mathrm{~h})$. The concentrate was comprised of $49.3 \%$ corn, $11.5 \%$ soybean meal, $30.0 \%$ beet pulp, $4.6 \%$ beet molasses, and $4.5 \%$ mineral mix. In addition, all cows received $3.0 \mathrm{~kg} \mathrm{DM} \mathrm{d}^{-1}$ of grass silage divided in equal amount after both milking times (08:00 $\mathrm{h}$ and 15:00 h). All cows had free access to water in the paddock.

\section{Grazing management}

The study took place on 20 ha sward dominated by perennial ryegrass (Lolium perenne L.), which was subjected to rotational grazing management. All treatments grazed at the same paddock, but were separated by an electric fence.

The area to be grazed each day was adjusted by herbage allowance and pre-grazing herbage mass. Pre- and postgrazing herbage mass was estimated through compressed surface height, using a rising plate meter (RPM, Ashgrove Plate Meter, Hamilton, New Zealand). One hundred RPM measurements were taken pre- and post-grazing, along a zigzag transect, in the grazing area of each treatment.

All groups were offered an herbage allowance (measured at ground level) of $21 \mathrm{~kg} \mathrm{DM} \mathrm{d}^{-1}$, which was allocated daily at 09:00 $\mathrm{h}$ (L-AM and H-AM treatments) or 16:00 h (L-PM and H-PM treatments). The cows stayed in the paddock all time, except during milking and silage supplementation.

\section{Food sampling and analyses}

Herbage samples were collected the days $14,21,28,35$, and 42 of the experiment at 09:00 $\mathrm{h}$ for L-AM and H-AM treatments, and 16:00 h for L-PM and H-PM treatments. Pasture samples were collected using the hand-plucking technique. Supplement samples (silage and concentrate) were collected the days 19,34, and 50 of the experiment. All food samples were frozen at $-20{ }^{\circ} \mathrm{C}$ after collection. Previous to chemical analysis, all samples were ground through a $1 \mathrm{~mm}$ screen 
(Willey Mill, 158 Arthur H, Thomas, Philadelphia, Pennsylvania, USA). Dry matter content was determined by means of an air oven at $60^{\circ} \mathrm{C}$ for $48 \mathrm{~h}$, ash by calcination in an oven at $550-600{ }^{\circ} \mathrm{C}$ for $5 \mathrm{~h}$, and ether extract (EE) and acid detergent fiber (ADF) by the AOAC procedure (AOAC, 1996), neutral detergent fiber (NDF) according to Van Soest et al. (1991). Crude protein (CP) was determined using LECO technology (AOAC, 2005), soluble protein (SP) and water soluble carbohydrates (WSC) were determined by Near Infrared Reflectance Spectroscopy (NIRS), pH and ammonia nitrogen $\left(\mathrm{NH}_{3}-\mathrm{N}\right)$ by AOAC (1996). Pasture, grass silage and concentrate metabolizable energy (ME) values were estimated by regression using a "D" value (digestible organic matter/DM × 100) (Garrido and Mann, 1981), determined in vitro (Tilley and Terry, 1963) according to Goering and Van Soest (1972).

\section{Dry matter intake}

Herbage DM intake (DMI) was calculated from energy requirements of the cows and ME content of the grass and supplements using the follow equation:

$$
\text { Herbage DMI }\left(k g d^{-1}\right)=\frac{\left(M E_{m}+M E_{m y}+M E_{l w c}+M E_{g}\right)-(\text { Conc } M E+\text { silage } M E)}{\text { Herbage } \mathrm{M}}
$$

where $M E_{m}, M E_{m y}, M E_{l w c}$, and $M E_{g}$ are the metabolizable energy (ME) requirements for maintenance, milk yield, and live weight change and gestation, respectively (Baker, 2004).

\section{Milk production and BCS}

Daily milk production was recorded with an automated system (MPC580 DeLaval, Tumba, Sweden). Milk samples were collected during morning and afternoon milking, on the days 19,33, 40, and 47 of the experiment. These samples were used to estimate protein, fat and urea in milk by infrared spectroscopy (Milko-scan, System 4300, Foss Electric, Hillerod, Denmark). BCS was recorded once per week after morning milking for one trained observer using a five point scale (Ferguson et al., 1994).

\section{Blood samples}

Coccygeal blood samples were collected on the days 14, 35, and 49 of the experiment. Blood samples were collected after afternoon milking using vacutainers containing lithium heparin. Blood samples were immediately centrifuged at $800 \times \mathrm{g}$ for $10 \mathrm{~min}$ at $4{ }^{\circ} \mathrm{C}$ and then plasma was collected and frozen at $-20{ }^{\circ} \mathrm{C}$ for subsequent analysis. Plasma was used to measure concentration of $\beta$-hydroxybutyrate $(\beta-\mathrm{HB}$; Ranbut, Randox Laboratories, Crumlin, County Antrim, Northern Ireland), urea (GLDH UV, HUMAN, Wiesbaden, Germany), albumin (Albumin liquicolor, HUMAN) and Cholesterol (Cholesterol liquicolor, HUMAN) by Wiener Metrolab 2300 auto-analyzer (Wiener Lab., Rosario, Argentina).

\section{Statistical analysis}

The experimental design was completely randomized where cows were kept in the same treatment throughout the study. Milk production, milk composition, $\mathrm{BW}, \mathrm{BCS}$, and blood parameters were analyzed as repeated measures in time by using the MIXED procedure (SAS Institute, 2003). The statistical model was:

$$
Y_{i j k l}=\mu+T_{i}+D_{j}+T D_{i j} C_{l}+e_{i j k}
$$

where $Y_{i j k l}$ is the dependent variable, $\mu$ is the overall mean, $T_{i}$ is the fixed effect of the $\mathrm{i}^{\text {th }}$ treatment, $D_{j}$ is the fixed effect of the $\mathrm{j}^{\text {th }}$ day, $T D_{i j}$ is the effect of the $\mathrm{ij}^{\text {th }}$ interaction between treatment and day, $C_{l}$ is the random effect of the $\mathrm{l}^{\text {th }}$ cow and $e_{i j k}$ is the random error.

Milk production, BW and BCS were analyzed including the pre-experimental period as a covariate. Comparison between treatments was carried out with Tukey test. Results were considered significant at $\mathrm{P}<0.05$ and tendency at $\mathrm{P}<0.1$.

\section{RESULTS}

Chemical compositions of feeds are presented in Table 1. DM content of the herbage was $20 \%$ greater $(\mathrm{P}<0.05)$ for H-PM and L-PM compared to L-AM. Similarly, water soluble carbohydrates (WSC) content was greater for H-PM and L-PM than L-AM $(\mathrm{P}<0.05)$. Herbage CP and SP contents were greater $(\mathrm{P}<0.05)$ for L-AM than other treatments. 
Table 1. Chemical composition of herbage and supplements offered to grazing dairy cows during the experiment.

\begin{tabular}{|c|c|c|c|c|c|c|c|c|c|c|}
\hline & \multicolumn{5}{|c|}{ Treatments } & \multicolumn{5}{|c|}{ Supplements } \\
\hline & L-AM & L-PM & H-AM & H-PM & SEM & P-Value & Grass silage & SEM & Concentrate & SEM \\
\hline DM, \% & $11.5 \mathrm{~b}$ & $14.3 \mathrm{a}$ & $12.1 \mathrm{ab}$ & $14.2 \mathrm{a}$ & 0.57 & $<0.001$ & 37.3 & 2.75 & 86.4 & 0.08 \\
\hline Ash, $\%$ & $10.7 \mathrm{a}$ & $10.1 \mathrm{ab}$ & $9.9 \mathrm{ab}$ & $9.6 b$ & 0.23 & 0.003 & 8.8 & 0.63 & 4.4 & 0.28 \\
\hline $\mathrm{CP}, \%$ & $33.2 \mathrm{a}$ & $27.6 \mathrm{~b}$ & $26.4 b$ & $23.7 b$ & 0.98 & $<0.001$ & 14.9 & 1.35 & 11.5 & 0.56 \\
\hline $\mathrm{SP}, \%$ & $12.8 \mathrm{a}$ & $10.6 \mathrm{~b}$ & $10.0 \mathrm{~b}$ & $8.9 b$ & 0.48 & $<0.001$ & - & - & - & - \\
\hline NDF, $\%$ & 49.5 & 48.1 & 50.5 & 48.1 & 1.92 & 0.77 & 46.6 & 1.28 & 32.3 & 1.29 \\
\hline $\mathrm{ADF}, \%$ & 21.8 & 21.6 & 23.4 & 23.3 & 0.52 & 0.06 & 28.9 & 0.45 & 15.5 & 0.91 \\
\hline $\mathrm{ME}$ & 2.80 & 2.82 & 2.75 & 2.75 & 0.03 & 0.24 & 2.80 & 0.01 & 3.10 & 0.05 \\
\hline WSC, \% & $5.72 b$ & $8.21 \mathrm{a}$ & 7.13ab & $8.78 \mathrm{a}$ & 0.24 & $<0.001$ & - & - & - & - \\
\hline WSC/CP & $0.18 \mathrm{c}$ & $0.30 \mathrm{ab}$ & $0.27 \mathrm{ab}$ & $0.38 \mathrm{a}$ & 0.02 & $<0.001$ & - & - & - & - \\
\hline $\mathrm{NFC}, \%$ & 9.6 & 11.3 & 11.6 & 14.7 & 0.00 & 0.55 & 25.5 & 1.12 & 49.5 & 1.31 \\
\hline $\mathrm{pH}$ & - & - & - & - & 0.55 & - & 4.3 & 0.16 & - & - \\
\hline $\mathrm{N}-\mathrm{NH}_{3}$ & - & - & - & - & - & - & 8.2 & 0.54 & - & - \\
\hline
\end{tabular}

Means with different lower-case letters within a row are different according to Tukey test $(\mathrm{P}<0.05)$.

L-AM: Low herbage mass delivered in the morning; L-PM: low herbage mass delivered in the afternoon; H-AM: high herbage mass delivered in the morning; H-PM: high herbage mass delivered in the afternoon; DM: dry matter; CP: crude protein; SP: soluble protein; NDF: neutral detergent fiber; ADF: acid detergent fiber; WSC: water soluble carbohydrates; ME: Mcal ME kg-1 DM; NFC: non-fibrous carbohydrates = 100 - $($ Ash $(\%)$ $+\mathrm{CP}(\%)+\mathrm{EE}(\%)+\mathrm{NDF}(\%))$.

Results of herbage mass and DMI are presented in Table 2. Pre and post-grazing herbage mass were greater $(\mathrm{P}<0.05)$ for H-AM and H-PM compared with L-AM and L-PM. Herbage and total DMI were similar among treatments $(\mathrm{P}>0.05)$, averaging 8.3 and $14.8 \mathrm{~kg} \mathrm{DM} \mathrm{cow}^{-1}$, respectively. Herbage WSC intake was greater for H-PM and lower for L-AM than other treatments $(\mathrm{P}<0.05)$. CP intake was affected by treatments $(\mathrm{P}<0.05)$, being greater for L-AM compared to L-PM and H-PM, but similar between L-AM and H-AM. ME intake was similar among treatments $(\mathrm{P}>0.05)$, averaging 42.2 Mcal ME cow $^{-1}$.

Results of milk production, milk composition and BCS are presented in Table 3. Milk production was $1.1 \mathrm{~kg}$ higher for H-PM than L-PM ( $<$ < 0.05). Protein and fat in milk were not affected by treatments, averaging 3.2\% and 3.9\%, respectively. Urea in milk was $22 \%$ higher for L-AM than any other treatment $(\mathrm{P}<0.05)$. Changes in BCS were not affected by treatments $(\mathrm{P}>0.05)$.

Results of blood metabolites are presented in Table 4. $\beta$-HB plasma concentration was $47 \%$ higher for AM compared with PM treatments $(\mathrm{P}<0.05)$. Similarly, urea plasma concentration was $30 \%$ higher for AM treatments $(\mathrm{P}<0.05)$. Albumin plasma concentration was affected by treatments $(\mathrm{P}<0.05)$, being lower for H-PM in comparison with other treatments. Cholesterol plasma concentration was not modified by treatments $(\mathrm{P}<0.05)$, averaging $4.6 \mathrm{mmol} \mathrm{L}^{-1}$.

It was observed an interaction between treatments L-PM and H-PM and blood sampling for $\beta$-HB, urea and albumin concentration in plasma $(\mathrm{P}<0.05)$ (Table 4). $\beta$-HB (Figure 1a) and urea (Figure 1b) concentrations were greater for L-AM and H-AM compared to L-PM and H-PM at week 2 and 3 of blood sampling. Plasma albumin concentration was lower for H-PM compared to other treatments at week 3 of blood sampling (Figure 1c).

Table 2. Herbage mass and dry matter (DM) intake and grazing behavior of grazing dairy cows receiving a low herbage mass in the morning (L-AM) or afternoon (L-PM) and high herbage mass in the morning (H-AM) or afternoon (H-PM).

\begin{tabular}{|c|c|c|c|c|c|c|}
\hline & \multicolumn{4}{|c|}{ Treatments } & \multirow[b]{2}{*}{ SEM } & \multirow[b]{2}{*}{ P-Value } \\
\hline & L-AM & L-PM & H-AM & H-PM & & \\
\hline \multicolumn{7}{|l|}{ Herbage mass, $0 \mathrm{~cm}$} \\
\hline Pre-grazing, kg DM ha-1 & $1853 b$ & $1847 b$ & $3078 \mathrm{a}$ & 2981a & 25.6 & $<0.01$ \\
\hline Post-grazing, $\mathrm{kg}$ DM ha-1 & $1224 b$ & $1198 b$ & $1424 a$ & $1424 \mathrm{a}$ & 7.7 & $<0.01$ \\
\hline \multicolumn{7}{|l|}{ Dry matter intake, $\mathrm{kg} \mathrm{DM}$ cow $^{-1}$} \\
\hline Herbage & 8.1 & 7.5 & 8.9 & 8.6 & 0.3 & 0.53 \\
\hline Total & 14.6 & 14.0 & 15.4 & 15.1 & 0.53 & 0.31 \\
\hline Water soluble carbohydrate & $0.46 \mathrm{c}$ & $0.62 \mathrm{~b}$ & $0.63 b$ & $0.75 \mathrm{a}$ & 0.04 & $<0.01$ \\
\hline Crude protein & $3.53 \mathrm{a}$ & $2.93 b$ & $3.19 \mathrm{ab}$ & $2.88 \mathrm{~b}$ & 0.14 & 0.01 \\
\hline ME, Mcal cow ${ }^{-1}$ & 41.9 & 40.5 & 43.7 & 42.8 & 1.48 & 0.48 \\
\hline
\end{tabular}

Means with different lower-case letters within a row are different according to Tukey test $(\mathrm{P}<0.05)$. 
Table 3. Milk production, milk composition, milk solids and change in body condition score of grazing dairy cows receiving a low herbage mass in the morning (L-AM) or afternoon (L-PM) and high herbage mass in the morning (H-AM) or afternoon (H-PM).

\begin{tabular}{|c|c|c|c|c|c|c|}
\hline & \multicolumn{4}{|c|}{ Treatments } & \multirow[b]{2}{*}{ SEM } & \multirow[b]{2}{*}{ P-Value } \\
\hline & L-AM & L-PM & H-AM & H-PM & & \\
\hline Milk production, $\mathrm{kg} \mathrm{d}^{-1}$ & $22.8 \mathrm{ab}$ & $22 b$ & $23.8 \mathrm{a}$ & $23.1 \mathrm{a}$ & 0.4 & 0.02 \\
\hline Milk fat, $\%$ & 3.95 & 3.76 & 3.76 & 3.92 & 0.14 & 0.65 \\
\hline Milk protein, $\%$ & 3.11 & 3.22 & 3.14 & 3.19 & 0.07 & 0.65 \\
\hline Milk urea, mmol L-1 & $4.58 \mathrm{a}$ & $3.97 \mathrm{~b}$ & $3.71 \mathrm{~b}$ & $3.62 \mathrm{~b}$ & 0.20 & $<0.01$ \\
\hline Milk solids, $\mathrm{kg} \mathrm{d}^{-1}$ & $1.70 \mathrm{ab}$ & $1.57 \mathrm{~b}$ & $1.91 \mathrm{ab}$ & $1.99 \mathrm{a}$ & 0.09 & 0.01 \\
\hline Change in BCS & -0.0012 & 0.0024 & -0.0021 & -0.0019 & 0.00 & 0.11 \\
\hline
\end{tabular}

Means with different lower-case letters within a row are different according to Tukey test $(\mathrm{P}<0.05)$.

BCS: Body condition score.

Table 4. Blood concentrations of grazing dairy cows receiving a low herbage mass in the morning (L-AM) or afternoon (L-PM) and high herbage mass in the morning (H-AM) or afternoon (H-PM).

\begin{tabular}{|c|c|c|c|c|c|c|c|c|}
\hline & \multicolumn{4}{|c|}{ Treatments } & \multirow[b]{2}{*}{ SEM } & \multicolumn{3}{|c|}{ P-value } \\
\hline & L-AM & L-PM & H-AM & H-PM & & Trt & Time & Trt $\times$ time \\
\hline$\beta$-HB, mmol L-1 & $0.97 \mathrm{a}$ & $0.62 b$ & $0.84 \mathrm{a}$ & $0.61 b$ & 0.04 & $<0.01$ & 0.45 & $<0.01$ \\
\hline Urea, mmol L-1 & $6.7 \mathrm{a}$ & $5.2 b$ & $6.3 \mathrm{a}$ & $4.8 \mathrm{~b}$ & 0.2 & $<0.01$ & $<0.01$ & 0.04 \\
\hline Albumin, $\mathrm{g} \mathrm{L}^{-1}$ & $43.7 \mathrm{a}$ & $41.7 \mathrm{a}$ & $42.4 \mathrm{a}$ & $39.9 b$ & 0.8 & 0.02 & 0.16 & $<0.01$ \\
\hline Cholesterol, mmol L-1 & 4.4 & 5.0 & 4.8 & 4.2 & 0.6 & 0.27 & 0.21 & 0.40 \\
\hline
\end{tabular}

Means with different lower-case letters within a row are different according to Tukey test $(\mathrm{P}<0.05)$.

$\beta$-HB: $\beta$ Hidroxybutyrate.

\section{DISCUSSION}

\section{Herbage composition}

The nutrient composition presented by the herbage during the experiment (Table 1) was lower in DM and higher in CP compared to the optimal composition recommended for dairy cows (Morales et al., 2014). In spite of some compositional imbalances during the season, about $20 \%$ of the annual yield produced had to be managed to optimize its inclusion in the diet (Schöbitz et al., 2013).

The lower concentration of DM registered for L-AM with respect to PM treatments, is explained by the water loss during the day and the effect of photosynthesis in products generated by the plant (Fulkerson and Donaghy, 2001; Pulido et al., 2015). On the other hand, the high content of CP and SP recorded in L-AM is explained by the combination effect of low herbage mass and AM schedule. This resulted in sward of vegetative state composed of leaves and young stems, with a low presence of dead material and high moisture content and non-protein $\mathrm{N}$, this being common in autumn, due to the lower growth rate of pastures (Keim et al., 2014; Ruiz-Albarrán et al., 2016b).

Regarding the WSC contents in the pastures offered in the morning and afternoon (average 64.3 and $84.9 \mathrm{~g} \mathrm{~kg}^{-1}$, respectively), these agree with the low values reported for the autumn season, associated with the lower number of light hours and lower solar radiation in fall (Pulido et al., 2015). The lower concentration of WSC registered in L-AM compared to PM treatments, would be explained because the WSC of the plant in L-AM treatment are consumed to a great extent during the night, besides the effect of reduced photosynthetic capacity of a pasture with low herbage mass (Fulkerson and Donaghy, 2001; Canseco et al., 2009).

\section{Pasture management and DMI}

Regarding the parameters of grazing management (Table 2), Canseco et al. (2009) recommends grazing intensities of 1400 to $1600 \mathrm{~kg} \mathrm{DM} \mathrm{ha}^{-1}$ for lactating dairy cows in autumn. In L-AM and L-PM treatments, average post-grazing residues of $1211 \mathrm{~kg} \mathrm{MS} \mathrm{ha}^{-1}$ were recorded. This residue would be expected given the lower pre-grazing herbage mass assigned to these treatments, which resulted in a $65 \%$ of herbage utilization by grazing, therefore, the cows made a greater effort to collect the herbage given the lower availability of pasture (Ruiz-Albarrán et al., 2012). 
Figure 1. Weekly variation of $\beta$-hydroxybutyrate $(\beta-\mathrm{HB})(\mathrm{a})$, urea (b), and albumin (c) of grazing dairy cows receiving a low herbage mass in the morning (L-AM) or afternoon (L-PM) and high herbage mass in the morning (H-AM) or afternoon (H-PM).
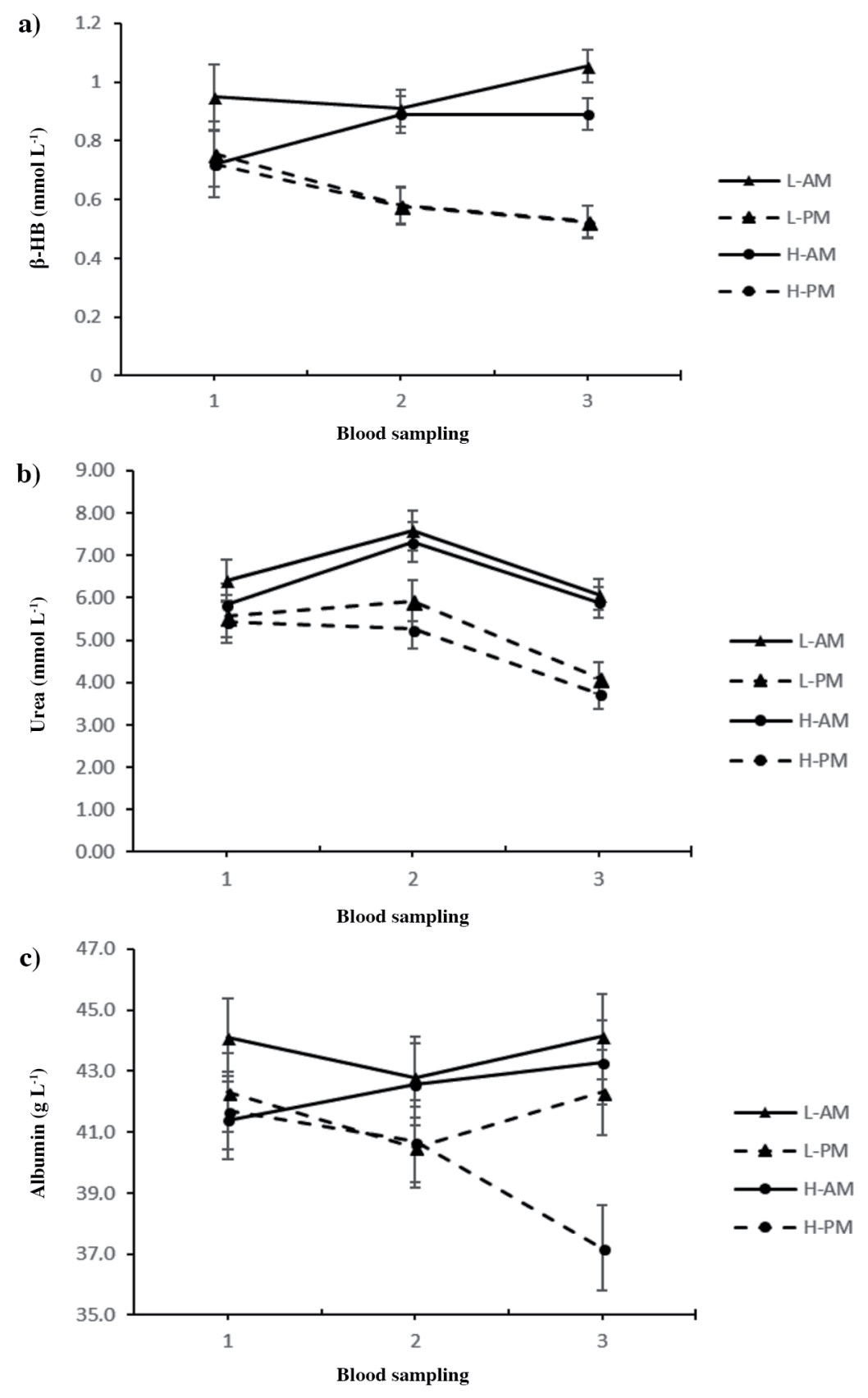

\section{Animal performance}

The greatest milk production for high herbage mass treatments (H-AM and H-PM) compared with L-PM, can be explained by the numerically greater herbage DMI (Table 3). These results indicate that it is possible to increase herbage DM intake through the intervention in grazing management in autumn, being the DMI an essential variable associated with the increase in milk production (Pérez-Prieto et al., 2012). However, Muñoz et al. (2016) reported a decrease in milk production by increasing the herbage mass from 2200 to $5000 \mathrm{~kg} \mathrm{DM} \mathrm{ha}^{-1}$ above $3 \mathrm{~cm}$ in spring, indicating that excessive herbage mass should be avoided since the quality of the forage decreases. 
Conversely, nonsignificant difference was observed in the treatments according to time of herbage allocation, indicating that although there are differences in the composition of the herbage, these were not enough to generate an increase in milk production (Pulido et al., 2015).

Milk protein and milk fat percentages were not affected by treatments, which can be explained by the similar energy intake among them and that the intake of NDF would not be a limiting factor in the diet (Schöbitz et al., 2013). However, given the higher milk production in H-PM compared to L-PM treatment -in spite of the similar milk compositions- a higher production of total milk solids was registered. Nonsignificant differences were recorded for BCS, mainly due to the similar energy intake as already explained.

\section{Blood metabolites}

The values of $\beta$-HB recorded in this study show a clear effect of the timing of herbage allocation, unlike those observed in milk production. The blood concentrations of $\beta$-HB mentioned above, agree with descriptions by Orr et al. (2001), indicating that the herbage in PM schedule has a higher concentration of DM and WSC and a lower concentration of CP (Pulido et al., 2015), which improves the synchrony between energy and protein at the ruminal level, and thus, would result in a decrease in the concentration of ketone bodies (Noro et al., 2011). The AM treatments presented values over the considered acceptable ( 0.1 to $0.6 \mathrm{mmol} \mathrm{L}^{-1}$ ) for dairy cows in early lactation (Raboisson et al., 2014). Thus, values $\geq 0.6$ $\mathrm{mmol} \mathrm{L}^{-1} \beta$-HB are considered indicators of negative energy balance. However, $\beta$-HB concentrations were not sufficient to be considered indicative of subclinical ketosis (> 1.2 or $\left.1.4 \mathrm{mmol} \mathrm{L}^{-1}\right)$ (Duffield et al., 2009; Cucunubo et al., 2013). The above described suggests that the herbage harvested by the PM treatments together with the supplementation offered, was sufficient to satisfy their nutritional requirements of maintenance and production, while the diet consumed by the AM treatments was slightly unbalanced but not enough to generate an effect on milk production (Morales et al., 2016). Emerging the question, if this imbalance can affect the health of the cows or they are able to adapt to these conditions. Besides, this imbalance was maintained over time (Figure 1a), and even increased in the last sampling, associated with a lower DM and WSC content, as the season progresses towards winter. Regarding the different herbage mass offered, there were no differences between the treatments, probably associated to the similar total energy intake of cows. The question arises if the treatments were not sufficiently contrasting (between herbage mass and/or excessive supplementation) (RuizAlbarrán et al., 2012). Finally, it should be considered that the concentrations of $\beta$-HB fluctuate during the day, product of the animal feeding pattern (Noro et al., 2011), so in this case, the modification of the $\beta$-HB concentrations would be due to a greater sensitivity to the variation in herbage composition (timing of herbage allocation) and not to the total nutrients intake during the day.

Regarding urea concentrations, its behavior in the different treatments was similar to $\beta$-HB, being the average values of each treatment within acceptable concentrations $\left(2.6-7.0 \mathrm{mmol} \mathrm{L}^{-1}\right)$. The higher urea blood concentrations in the AM treatments are explained by a higher intake of $\mathrm{CP}$, due to a greater concentration of this in the herbage associated with a lower concentration of DM, ME, and WSC (especially during second sampling, Figure 1b). This quickly increased blood urea concentrations, as reported by Pulido et al. (2015).

It is important to note, that L-AM treatment recorded the highest concentration of blood urea, while the H-PM treatment recorded the lowest concentration of urea. This shows that there is an interaction between the evaluated factors, where the pasture of $2000 \mathrm{~kg} \mathrm{DM} \mathrm{ha}^{-1}$ offered in AM schedule showed the highest values of CP and SP and lower values of WSC and $\mathrm{WSC} / \mathrm{CP}$ ratio. This indicates that the ammonium utilization capacity of the ruminal microorganisms was exceeded for L-AM, being absorbed and then transformed into urea in the liver (Morales et al., 2016). Urea is a product of $\mathrm{N}$ excretion, which represents an energy expenditure for the animal, so an increase in the production of ammonium and urea decreases the production efficiency. Therefore, in more contrasting conditions (lower ME intake, less energy supplementation or more unbalanced herbages) a marked negative effect on milk production would be expected.

Plasma albumin is a blood metabolite that provides information about the animal protein balance. This is synthesized in the liver from amino acids, constituting approximately $50 \%$ of plasma proteins, so its concentration reflects the ability of the animal to synthesize and store proteins (Wittwer, 2000). In addition, the synthesis of albumin also reflects health status (it is modified by hepatic alterations or by chronic digestive losses) (Noro et al., 2006). The values obtained, although they are slightly elevated (29-41 $\mathrm{g} \mathrm{L}^{-1}$ ), can be considered as normal (Alberghina et al., 2011; Wittwer, 2012), since they would not be indicators of a protein deficiency. In addition to this, in lactating peak cows, a positive correlation is reported 
between the increase in milk production and albumin concentrations (Al-Mujalli, 2008), similarly reported by Noro et al. (2011). Moreover, lower concentrations recorded in the last sampling in H-PM treatment (Figure 1c), would be associated to an individual effect, where the variability in changes in albumin concentration may be due to variations in the rates of albumin synthesis by the liver (Wittwer, 2000; Al-Mujalli, 2008).

The stable and similar concentrations of cholesterol registered in the different treatments (reference interval 2.7-5.3 $\mathrm{mmol} \mathrm{L}^{-1}$ ), are explained because this metabolite increases its concentrations steadily from the second postpartum week until the eighth week, reaching its maximum value in the fourteenth week (Ceballos et al., 2002; Kessler et al., 2014). Therefore, during the development of this study, concentrations were on level. In addition, it is reported that serum cholesterol is positively associated with milk production and feed intake, registering higher concentrations cows receiving a higher energy intake supplementation (Ceballos et al., 2002; Józwik et al., 2012). Thus, the similar values registered in the study, confirm the similar DM and energy intake between treatments.

These results confirm that offer the new strip of pasture in PM time to early lactation cows in autumn modify the herbage composition (Gregorini, 2012), and this is reflected in an improvement in the metabolic status of cows due to a better nutrient supply. In addition, when the pasture is allocated in PM and combined with a high herbage mass, impacted positively in milk production and composition, supporting the positive effect of both factors. Similar studies in the future should consider the daily nutritional balance and its effect on the circadian metabolic profile of animals.

\section{CONCLUSIONS}

Under the conditions of this study, offering a high herbage mass (3000 kg DM ha-1) in PM time (after afternoon milking), resulted in a higher milk production and milk solids compared with lower herbage mass PM treatment (2000 kg DM $\left.\mathrm{ha}^{-1}\right)$. There was not effect of herbage mass or time of allocation of the pasture on fat and protein composition nor body condition score and total energy intake.

Offer a new strip grazing in PM schedule, generated a decreased in blood concentrations of $\beta$-hydroxybutyrate and urea, product of an increase in water soluble carbohydrates (WSC) intake, WSC/crude protein (CP) ratio and a reduction of $\mathrm{CP}$ intake, not affecting the albumin and cholesterol concentrations. No differences were found in blood metabolites concentrations according to the different herbage mass offered.

\section{ACKNOWLEDGEMENTS}

The support of the Vicerrectoría de Investigación, Desarrollo y Creación Artística is acknowledged for financing the project DID S-2016-01.

\section{REFERENCES}

Alberghina, D., Giannetto, C., Vazzana, I., Ferrantelli, V., and Piccione, G. 2011. Reference intervals for total protein concentration, serum protein fractions, and albumin/globulin ratios in clinically healthy dairy cows. Journal of Veterinary Diagnostic Investigation 23:111-114.

Al-Mujalli, A.A.M. 2008. Studies on some serum constituents of dairy cows in Saudi Arabia. Scientific Journal of King Faisal University 9(2):105-114.

AOAC. 1996. Official methods of analysis. $16^{\text {th }}$ ed. Association of Official Analytical Chemists (AOAC), Washington DC., USA.

AOAC. 2005. Official methods of analysis. $18^{\text {th }}$ ed. Association of Official Analytical Chemists (AOAC), Washington DC., USA.

Badgery, W., Millar, G., Broadfoot, K., Martin, J., Pottie, D., Simmons, A., et al. 2017. Better management of intensive rotational grazing systems maintains pastures and improves animal performance. Crop and Pasture Science 68:1131-1140.

Baker, R.D. 2004. Estimating herbage intake from animal performance. p. 95-120. In Penning, P.D. (ed.) Herbage intake handbook. British Grassland Society, Reading, UK.

Canseco, C., Abarzúa, A., Parga, J., Teuber, N., Balocchi, O., Lopetegui, J., et al. 2009. Calidad nutritiva de las praderas. p. 51-67. In Teuber, N., Balocchi, O., and Parga, J. (eds.) Manejo del pastoreo. Fundación para la Innovación Agraria (FIA), Santiago, Chile. 
Ceballos, A., Gómez, P.M., Vélez, M.L., Villa, N.A., y López, L.F. 2002. Variación de los indicadores bioquímicos del balance de energía según el estado productivo en bovinos lecheros de Manizales, Colombia. Revista Colombiana de Ciencias Pecuarias 15(1):13-25.

Cucunubo, L., Strieder-Barboza, C., Wittwer, F., y Noro, M. 2013. Diagnóstico de cetosis subclínica y balance energético en vacas lecheras mediante el uso de muestras de sangre, orina y leche. Revista Científica de la Facultad de Ciencias Veterinarias de la Universidad del Zulia 23:111-119.

Duffield, T.F., Lissemore, K.D., McBride, B.W., and Leslie, K.E. 2009. Impact of hyperketonemia in early lactation dairy cows on health and production. Journal of Dairy of Science 92:571-580.

Ferguson, J.D., Galligan, D.T., and Thomsen, N. 1994. Principal descriptors of body condition score in Holstein cows. Journal of Dairy Science 77:2695-2703.

Fulkerson, W.J., and Donaghy, D.J. 2001. Plant soluble carbohydrate reserves and senescence- key criteria for developing an effective grazing management system for ryegrass- based pastures: a review. Australian Journal of Experimental Agriculture 41:261-275.

Garrido, O., y Mann, E. 1981. Composición química, digestibilidad y valor energético de una pradera permanente de pastoreo a través del año. Memoria de título. Universidad Austral de Chile, Facultad de Ciencias Agrarias, Valdivia, Chile.

Goering, H., y Van Soest, P. 1972. Análisis de fibra de forraje. Universidad Agraria La Molina, Lima, Perú.

Gregorini, P. 2012. Diurnal grazing pattern: its physiological basis and strategic management. Animal Production Science 52:416-430

Józwik, A., Strzalkowska, N., Bagnicka, E., Grzybek, W., Krzyzewski, J., and Polawska, E., et al. 2012. Relationship between milk yield, stage of lactation, and some blood serum metabolic parameters of dairy cows. Czech Journal of Animal Science 57(8):353-360.

Keim, J.P., López, I.F., and Berthiaume, R. 2014. Nutritive value, in vitro fermentation and methane production of perennial pastures as affected by botanical composition over a growing season in the south of Chile. Animal Production Science 54:598-607.

Kessler, E.C., Gross, J.J., Bruckmaier, R.M., and Albrecht, C. 2014. Cholesterol metabolism, transport, and hepatic regulation in dairy cows during transition and early lactation. Journal of Dairy Science 97:1-10.

Morales, A., Grob, D., Balocchi, O., and Pulido, R. 2014. Productive and metabolic response to two levels of corn silage supplementation in grazing dairy cows in early lactation during autumn. Chilean Journal of Agricultural Research 74:205-212.

Morales, A., Grob, D., Wittwer, F., Muller, A., Balocchi, O., and Pulido, R. 2016. Evaluation of blood metabolites in dairy cows grazing under two pasture allowances and supplemented with corn silage under restricted grazing conditions. Revista Brasileira de Zootecnia 45:686-692.

Muñoz, C., Letelier, P.A., Ungerfeld, E.M., Morales, J.M., Hube, S.L., and Pérez-Prieto, A. 2016. Effects of pregrazing herbage mass in late spring on enteric methane emissions, dry matter intake, and milk production of dairy cows. Journal of Dairy Science 99(10):7945-7955.

Noro, M., Borkert, J., Hinostroza, G.A., Pulido, R., y Wittwer, F. 2011. Variaciones diarias de metabolitos sanguíneos y su relación con el comportamiento alimenticio en vacas lecheras a pastoreo primaveral. Revista Científica de la Facultad de Ciencias Veterinarias de la Universidad del Zulia 21:25-130.

Noro, M., Vargas, V., Pulido, R.G., y Wittwer, F. 2006. Efecto del tipo de concentrado sobre indicadores sanguíneos del metabolismo de energía y de proteínas en vacas lecheras en pastoreo primaveral. Archivos de Medicina Veterinaria 38(3):227-232.

Orr, R.J., Rutter, S.M., Penning, P.D., and Rook, A.J. 2001 . Matching grass supply to grazing patterns for dairy cows. Grass and Forage Science 56(4):352-361.

Pérez-Prieto, L.A., Peyraud, J.L., and Delagarde, R. 2012. Does pre-grazing herbage mass really affect herbage intake and milk production of strip grazing dairy cows? Grass and Forage Science 68(1):93-109.

Pulido, R.G., Ruiz-Albarrán, M., Balocchi, O.A., Nannig, P., and Wittwer, F. 2015. Effect of timing of pasture allocation on production, behavior, rumen function, and metabolism of early lactating dairy cows during autumn. Livestock Science 177:43-51.

Raboisson, D., Mounié, M., and Maigné, E. 2014. Diseases, reproductive performance, and changes in milk production associated with subclinical ketosis in dairy cows: A meta-analysis and review. Journal of Dairy Science 97:7547-7563.

Roche, J.R., Berry, D.P., Bryant, A.M., Burke, C.R., Butler, S.T., Dillon, P.G., et al. 2017. A 100-year review: A century of change in temperate grazing dairy systems. Journal of Dairy Science 100:10189-10233.

Roche, J.R., Friggens, N.C., Kay, J.K., Fisher, M.W., Stafford, K.J., and Berry, D.P. 2009. Body condition score and its association with dairy cow productivity, health, and welfare. Journal of Dairy Science 92:5769-5801.

Roche, J.R., Macdonald, K.A., Schütz, K.E., Matthews, L.R., Verkerk, G.A., Meier, S., et al. 2013. Calving body condition score affects indicators of health in grazing dairy cows. Journal of Dairy Science 96:5811-5825.

Ruiz-Albarrán, M., Balocchi, O.A., Noro, M., Wittwer, F., and Pulido, R.G. 2012. Effect of increasing pasture allowance and grass silage on animal performance, grazing behavior and rumen fermentation parameters of dairy cows in early lactation during autumn. Livestock Science 150:407-413. 
Ruiz-Albarrán, M., Balocchi, O.A., Noro, M., Wittwer, F., and Pulido, R.G. 2016a. Effect of the type of silage on milk yield, intake and rumen metabolism of dairy cows grazing swards with low herbage mass. Animal Science Journal 87:878-884.

Ruiz-Albarrán, M., Balocchi, O.A., Wittwer, F., and Pulido, R.G. 2016b. Milk production, grazing behavior and nutritional status of dairy cows grazing two herbage allowances during winter. Chilean Journal of Agricultural Research 76:34-39. doi: $10.4067 /$ S0718-58392016000100005.

SAS Institute. 2003. Statistical Analysis Systems. Version 9.1 for windows. SAS Institute, Cary, North Carolina, USA.

Schöbitz, J., Ruiz-Albarrán, M., Balocchi, O.A., Wittwer, F., Noro, M., and Pulido, R.G. 2013. Effect of increasing pasture allowance and concentrate supplementation on animal performance and microbial protein synthesis in dairy cows. Archivos de Medicina Veterinaria 45:247-258.

Sundrum, A. 2015. Metabolic disorders in the transition period indicate that the dairy cows' ability to adapt is overstressed. Animals 5:978-1020.

Tilley, J.M.A., and Terry, R.A. 1963. A two stage technique for in vitro digestion of forage crops. Journal of the British Grassland Society 18:104-111.

Van Soest,P.J., Robertson J., and Lewis, B. 1991. Methods for dietary fiber, neutral detergent fiber, and nonstarch polysaccharides in relation to animal nutrition. Journal of Dairy Science 74:3583-3595.

Vibart, R.E., Tavendale, M., Otter, D., Schwendel, B.H., Lowe, K., Gregorini, P., et al. 2017. Milk production and composition, nitrogen utilization, and grazing behavior of late-lactation dairy cows as affected by time of allocation of a fresh strip of pasture. Journal of Dairy Science 100(7):5305-5318.

Wims, C.M., Deighton, M.H., Lewis, E., O’Loughlin, B., Delaby, L., Boland, T.M., et al. 2010. Effect of pregrazing herbage mass on methane production, dry matter intake, and milk production of grazing dairy cows during the mid-season period. Journal of Dairy Science 93:4976-4985.

Wittwer, F. 2000. Diagnóstico dos desequilíbrios metabólicos de energía em rebanhos bovinos. In Gonzalez, F., Barcellos, J., Ospina, H., e Ribeiro, L. (eds.) Perfil metabólico em ruminantes: seu uso em nutrição e doenças nutricionais. Universidade Federal Do Río Grande Do Sul, Porto Alegre, Brasil.

Wittwer, F. 2012. Manual de patología clínica veterinaria. 2a ed. Universidad Austral de Chile, Valdivia, Chile. 